Sains Malaysiana 50(4)(2021): 1017-1025

http://doi.org/10.17576/jsm-2021-5004-12

\title{
Kesan Penyahasidan dan Penambahan Perisa Lemon terhadap Ciri Antioksidan Ekstrak Mengkudu
}

(Effect of Deacidification and Lemon Flavour Addition on the Antioxidant Capacity of Noni Extract)

\author{
Ain Nadiah Sofiah Ahmad Khorairi, Haslaniza Hashim \& Mohamad Yusof Maskat*
}

\begin{abstract}
ABSTRAK
Ekstrak mengkudu (Morinda citrifolia) mempunyai kesan yang baik terhadap kesihatan. Namun begitu, pengambilannya masih terhad kerana rasa masam serta bau ekstrak mengkudu yang tidak digemari oleh pengguna. Penggunaan kaedah penyahasidan dan penambahan bahan perisa dilihat dapat mengurangkan rasa masam buah mengkudu tetapi kesan kepada ciri-ciri antioksidan masih tidak diketahui. Oleh itu, kajian ini dijalankan bertujuan untuk menentukan kesan penyahasidan dan penambahan 0, 4 dan 8\% perisa lemon terhadap ciri antioksidan ekstrak mengkudu. Analisis yang dijalankan ke atas ekstrak mengkudu adalah penilaian nilai $p H$, ujian jumlah kandungan fenol (TPC), ujian penangkapan radikal bebas (DPPH) dan ujian kuasa penurunan ferik (FRAP). Hasil kajian mendapati bahawa nilai pH meningkat secara signifikan $(p<0.05)$ setelah dinyahasid. Manakala, nilai TPC, DPPH dan FRAP ekstrak mengkudu pula menurun secara signifikan $(p<0.05)$ setelah dinyahasid. Penambahan bahan perisa lemon ke dalam sampel ekstrak mengkudu ternyahasid, tidak memberikan perubahan signifikan pada nilai pH, TPC, DPPH dan FRAP. Secara keseluruhannya, rawatan penyahasidan membantu mengurangkan keasidan ekstrak mengkudu tetapi penambahan bahan perisa lemon tidak memberikan kesan signifikan kepada ciri antioksida ekstrak mengkudu.

Kata kunci: Antioksidan; lemon; mengkudu; penyahasidan; $p H$
\end{abstract}

\section{ABSTRACT}

Noni extract (Morinda citrifolia) has been shown to have beneficial health effect. However, the consumption of noni extract is still limited due to the sour taste and less desired odour among the consumers. Use of deacidification and flavor addition might reduce the sour taste of noni but its effect on the antioxidative properties are not known. Hence, this study was conducted to determine the effect of deacidification process and addition of 0, 4 and 8\% of lemon flavoring agent on the antioxidant characteristics of noni extract. The analyses conducted on noni extract were $\mathrm{pH}$ value, total phenolic content (TPC), free radical scavenging ability (DPPH) and ferric reducing power (FRAP). Results showed that $p H$ values increased significantly $(p<0.05)$ after deacidification, whereas the TPC, DPPH and FRAP of noni extract decreased significantly $(p<0.05)$ after deacidification. The addition of flavoring to deacidified noni extract samples did not produce any significant effect on $\mathrm{pH}, T P C, D P P H$, and FRAP. In general, deacidification method helps in reducing the acidity of noni extract but addition of lemon flavor did not showed any significant effect on the antioxidant characteristic of noni extract.

Keywords: Antioxidant; deacidification; lemon; noni; $\mathrm{pH}$

\section{PENDAHULUAN}

Mengkudu dengan nama saintifik Morinda citrifolia Linn. adalah tumbuhan ubatan yang telah digunakan di seluruh dunia selama berabad-abad lamanya. Mengkudu berasal dari Asia Tenggara iaitu meliputi kawasan Indonesia hingga ke Australia dan ditanam di Polinesia, India, Caribbean dan di tengah dan utara Amerika Selatan (Dixon et al. 1999; Ross 2001). Semua bahagian pokok mengkudu telah digunakan sebagai ubat-ubatan herba di Polinesia selama lebih 2000 tahun (Anh et al. 2006). Kajian melaporkan bahawa semua bahagian tanaman mengkudu mempunyai pelbagai faedah kesihatan termasuk ciri-ciri pencegahan penyakit (Singh 2012). Oleh kerana nilai perubatan dan pemakanannya, mengkudu dianggap 'Ratu' daripada 80 spesies lain dalam keluarga Rubiaceae (Morton 1992). Tumbuhan mengkudu juga sering dikaitkan sebagai penawar semula jadi yang merendahkan 
tekanan darah, mengurangkan pembengkakan sendi, memberhentikan jangkitan dalaman dan luaran serta menghalang pertumbuhan sel kanser daripada berkembang (Wang et al. 2002).

Walaupun kini terdapat pengeluar syarikat makanan yang mengeluarkan produk mengkudu dalam pelbagai bentuk seperti jus, serbuk dan kapsul (Maskat \& Tan 2011), disebabkan oleh isi buah mengkudu yang pahit dan masam serta baunya yang busuk dan tidak menyenangkan telah mengurangkan kadar penerimaan orang ramai terhadap produk berasaskan ekstrak mengkudu (Anh et al. 2006). Manipulasi kandungan asid melalui proses penyahasidan merupakan salah satu langkah untuk memperbaiki rasa masam ekstrak mengkudu supaya lebih diterima pengguna. Antara kaedah penyahasidan yang biasa dijalankan untuk produk makanan adalah dengan menggunakan serbuk karbon yang diaktifkan (Khalafu et al. 2017; Sin et al. 2018), kalsium karbonat (Nur Hafiza et al. 2010) dan resin penukar ion berasaskan polimer seperti Amberlite IRA-67 (Fong et al. 2017; Haslaniza et al. 2015a), DuoliteA7 (Haslaniza et al. 2015a) dan Sephadex LH-20 (Nazrul et al. 2013).

Kajian lepas oleh Haslaniza et al. (2015a) mendapati bahawa resin penukar anion bes lemah berpotensi untuk menyahasidkan jus mengkudu. Ini disebabkan oleh kehadiran kumpulan amina tertier yang bertindak sebagai kumpulan berfungsi di dalam matriks polimer akrilik rantaian silang yang menjerap kumpulan karbonil daripada asid oktanoik dengan anion daripada tapak resin. Selain itu, penggunaan resin penukar ion bes lemah ini juga dapat meminimumkan kehilangan antioksida yang penting dalam jus mengkudu tersebut. Kebolehulangan (regenerasi) resin turut menyumbang kepada penggunaannya yang meluas dan tidak terhad kepada industri makanan sahaja.

Penggunaan bahan perisa untuk memperbaiki rasa produk minuman dilihat mempunyai potensi yang tinggi dalam menghasilkan rasa produk yang digemari. Antara kajian lepas yang telah dijalankan adalah penambahan jus oren dalam minuman probiotik (Luckow et al. 2006), jus strawberi dalam susu kambing (Wang et al. 2019) dan campuran serai dan jus limau dalam minuman berasaskan soya (Kieling \& Prudencio 2019). Walaupun terdapat kajian terdahulu seperti yang telah dinyatakan, tiada kajian yang melibatkan kesan gabungan langkah penyahasidan dan penambahan perisa terhadap ciri antioksidan produk ekstrak mengkudu. Justeru, kajian ini dijalankan untuk menentukan kesan gabungan penyahasidan dan penambahan bahan perisa lemon terhadap ciri-ciri antioksidan ekstrak mengkudu.

\section{BAHAN DAN KAEDAH}

Buah mengkudu pada tahap kematangan 4 (Chan-Blanco et al. 2006) diperam selama 3 hari sebelum dibersihkan dengan air suling. Penyediaan ekstrak buah mengkudu adalah mengikut kaedah yang digunakan oleh Cheah et al. (2014). Buah yang telah dikeringkan dipotong kecil kira-kira 2 hingga $4 \mathrm{~cm}$, ditambah dengan air suling pada nisbah 1:1 (berat:isipadu) dan seterusnya dikisar menggunakan pengisar (Cornell, Malaysia). Jus yang terhasil ditapis dengan menggunakan kain kasa. Kemudian diemparkan dengan mesin pengempar (5810R - Eppendorf Centrifuge, Jerman) pada kelajuan $4000 \mathrm{rpm}$ selama 25 min bagi mengasingkan pulpa yang masih terdapat dalam jus mengkudu. Bahan perisa yang digunakan adalah bahan perisa tiruan bergred makanan; esen lemon yang diperoleh dari Yummies Bakery Ingredients.

\section{RESIN PENUKAR ION}

Amberlite IRA-67 atau resin penukar anion berbes lemah berasaskan polimer diperoleh dari Fluka, Rohm and Haas Company, Perancis dengan kelulusan penggunaannya dalam pemprosesan makanan oleh Food and Drug Administration (FDA). Pengkondisian resin Amberlite IRA67 dilakukan menggunakan $\mathrm{HCl}(5 \%)$ mengikut kajian Haslaniza et al. (2015b). Nilai pH ekstrak mengkudu (4.2) diubah kepada $\mathrm{pH} 7$ dengan penambahan natrium hidroksida $(\mathrm{NaOH})$ pada suhu bilik. Kemudiaan, ekstrak mengkudu dicampurkan dengan $8 \%(\mathrm{w} / \mathrm{v})$ resin Amberlite IRA-67 yang telah dikondisikan dalam kelalang Erlenmeyer $250 \mathrm{~mL}$ dan digoncang menggunakan pengoncang inkubator (Model WIS 20 - WiseCube, Korea) selama 2 jam pada suhu $30{ }^{\circ} \mathrm{C}$ dengan kelajuan $120 \mathrm{rpm}$. Selepas itu, campuran tersebut ditapis menggunakan kertas turas untuk menghasilkan ekstrak mengkudu yang ternyahasid. Penambahan bahan perisa tiruan lemon dilakukan ke atas ekstrak mengkudu tanpa penyahsidan dan ekstrak mengkudu yang ternyahasid dengan peratusan kepekatan yang berbeza iaitu 0,4 dan $8 \%(\mathrm{v} / \mathrm{v})$. Campuran ini kemudian dikacau sehingga sebati pada suhu bilik. Perlakuan ini menghasilkan enam sampel yang berbeza iaitu ekstrak mengkudu asli (tanpa penyahasidan dan $0 \%$ perisa lemon), ekstrak mengkudu asli dengan $4 \%$ perisa lemon, ekstrak mengkudu asli dengan $8 \%$ perisa lemon, ekstrak mengkudu ternyahasid dengan $0 \%$ perisa lemon, ekstrak mengkudu ternyahasid dengan $4 \%$ perisa lemon dan ekstrak mengkudu ternyahasid dengan $8 \%$ perisa lemon. 
PENGUKURAN NILAI PH

Pengukuran nilai $\mathrm{pH}$ dilakukan menggunakan meter $\mathrm{pH}$ (Model PHM 210- MeterLab). Meter pH dikalibrasikan dengan larutan penimbal pH 4.0 dan 7.0 sebelum pengukuran sampel dilakukan. Pengukuran nilai $\mathrm{pH}$ dilakukan pada suhu bilik dengan menggunakan $10 \mathrm{~mL}$ sampel.

\section{JUMLAH KANDUNGAN FENOL}

Jumlah kandungan fenol ditentukan dengan menggunakan reagen Folin-Ciocalteu (Slinkard \& Singleton 1977; Yang et al. 2011). Sebanyak $0.1 \mathrm{~mL}$ ekstrak mengkudu dicampurkan dengan $0.9 \mathrm{~mL}$ air suling. Campuran ini ditambah dengan $5 \mathrm{~mL}$ reagen Folin-Ciocalteu dan dibiarkan selama $10 \mathrm{~min}$. Kemudian, sebanyak $4 \mathrm{~mL}$ larutan $7.5 \%$ natrium karbonat ditambahkan dalam campuran tersebut sebelum dibiarkan selama 2 jam dalam keadaan gelap di dalam 96-well plate. Bacaan penyerapan sampel dinilai dengan menggunakan pembaca mikroplat UV-Vis berjenama Epoch (model Biotech 259037) pada gelombang $765 \mathrm{~nm}$. Pengukuran bacaan penyerapan sampel pengosong dilakukan dengan menggantikan ekstrak mengkudu dengan air suling. Jumlah kandungan fenol ekstrak mengkudu dihitung dengan menggunakan nilai yang didapati daripada lengkuk piawai dan dinyatakan sebagai mg asid galik per 1L ekstrak mengkudu. Pengiraan kandungan fenol adalah seperti berikut:

Jumlah kandungan fenol (GAE) dalam ekstrak mengkudu $(\mathrm{mg} \mathrm{GAE} / \mathrm{L})=\mathrm{R} \times \mathrm{D}$

dengan $\mathrm{R}$ ialah bacaan daripada lengkuk piawai (asid galik) dan $\mathrm{D}$ ialah faktor pencairan $=10$.

\section{UJIAN PENANGKAPAN RADIKAL (DPPH)}

Kuasa penangkapan radikal bebas ekstrak mengkudu diukur berdasarkan kaedah Akowuah et al. (2005). Larutan 0.1 mM DPPH (2,2-difenil-1-pikrilhidrazil) digunakan sebagai larutan stok piawai dan disediakan secara segar setiap kali digunakan. Sebanyak 2 mg serbuk DPPH dilarutkan dengan metanol dan dipenuhkan sehingga $50 \mathrm{~mL}$ dalam kelalang volumetrik. Sebanyak $200 \mu \mathrm{L}$ ekstrak mengkudu dicampur dengan $2 \mathrm{~mL}$ larutan $0.1 \mathrm{mM}$ DPPH dan $0.8 \mathrm{~mL}$ larutan metanol dan dibiarkan dalam keadaan gelap pada suhu bilik selama 1 jam. Seterusnya, sebanyak $200 \mu \mathrm{L}$ larutan daripada campuran tersebut diambil untuk mengukur bacaan penyerapan pada gelombang $517 \mathrm{~nm}$ dengan menggunakan pembaca mikroplat UV-Vis berjenama Epoch (model Biotech 259037). Sampel pengosong disediakan melalui campuran $2 \mathrm{~mL}$ larutan DPPH dan $1 \mathrm{~mL}$ metanol. Kuasa penangkapan radikal bebas ekstrak mengkudu dihitung dengan menggunakan formula berikut:
$\%$ Penangkapan $\mathrm{DPPH}=[(\mathrm{AC}-\mathrm{AS}) / \mathrm{AC}] \times 100 \%$

dengan AC ialah bacaan penyerapan sampel pengosong (larutan DPPH) dan AS ialah bacaan penyerapan sampel ekstrak mengkudu selepas 1 jam.

\section{KUASA PENURUNAN FERIK (FRAP)}

Penyedian larutan reagen bagi ujian kuasa penurunan ferik dilakukan berdasarkan kaedah Benzie dan Strain (1996). Larutan 0.3 M penimbal asetat pada $\mathrm{pH} 3.6$ disediakan melalui campuran $0.31 \mathrm{~g}$ natrium asetat trihidrat $\left(\mathrm{CH}_{3} \mathrm{COONa} .3 \mathrm{H}_{2} \mathrm{O}\right), 1.6 \mathrm{~mL}$ asid asetat glasial dan 100 $\mathrm{mL}$ air suling. Larutan $40 \mathrm{mM} \mathrm{HCl}$ disediakan dengan mencampurkan $1.67 \mathrm{~mL}$ larutan $12 \mathrm{M}$ asid $\mathrm{HCl}$ dengan $500 \mathrm{~mL}$ air suling. Seterusnya, larutan $10 \mathrm{mM}$ TPTZ dihasil dengan melarutkan $0.1562 \mathrm{~g}$ serbuk TPTZ dengan 40 $\mathrm{mM} \mathrm{HCl}$. Bagi larutan $20 \mathrm{mM} \mathrm{FeCl}_{3} \cdot 6 \mathrm{H}_{2} \mathrm{O}$ pula, larutan tersebut dihasilkan melalui pencampuran $0.2703 \mathrm{~g}$ serbuk $\mathrm{FeCl}_{3} \cdot 6 \mathrm{H}_{2} \mathrm{O}$ dengan air suling sehingga larut kesemuanya dan akhirnya dipenuhkan sehingga $50 \mathrm{~mL}$. Reagen FRAP disediakan melalui pencampuran ketiga-tiga larutan reagen pada nisbah 10:1:1 dan dipanaskan sehingga 37 ${ }^{\circ} \mathrm{C}$ sebelum digunakan.

Penentuan FRAP bagi ekstrak mengkudu dijalankan berdasarkan kaedah Delgado-Andrade et al. (2010). Sebelum analisis dijalankan, ekstrak mengkudu dicairkan kepada 100 kali ganda dengan menggunakan air suling. Sebanyak $900 \mu \mathrm{L}$ reagen FRAP yang segar telah dicampur dengan $100 \mu \mathrm{L}$ ekstrak mengkudu dan diredam pada $37{ }^{\circ} \mathrm{C}$ selama $30 \mathrm{~min}$. Kemudian, $200 \mu \mathrm{L}$ daripada campuran tersebut dipipetkan ke dalam lekuk mikroplat dan bacaan penyerapan diambil pada gelombang 595 $\mathrm{nm}$ dengan menggunakan pembaca mikroplat UV-Vis berjenama Epoch (model Biotech 259037). Langkah yang sama digunakan untuk menghasilkan lengkuk piawai dengan menggunakan larutan $\mathrm{FeSO}_{4} \cdot 7 \mathrm{H}_{2} \mathrm{O}$. Nilai kuasa penurunan ferik dinyatakan sebagai $\mu \mathrm{mol} \mathrm{Fe}(\mathrm{II}) / \mathrm{mL}$ ekstrak mengkudu dan dihitung seperti berikut:

Nilai penurunan ferik $(\mu \mathrm{mol} \mathrm{Fe}(\mathrm{II}) / \mathrm{mL})=\mathrm{R} \times \mathrm{D}$

dengan $\mathrm{R}$ ialah bacaan daripada lengkuk piawai dan $\mathrm{D}$ ialah faktor pencairan $=100$.

\section{ANALISIS STATISTIK}

Data yang diperoleh daripada analisis fizikokimia dianalisis dengan ujian statistikal ANOVA dan ujian Duncan menggunakan perisian Statistical Analysis System (SAS) versi 9.3, 2011. Manakala data daripada penilaian sensori dianalisis menggunakan perisian Statistical Package For Social Science (SPSS) versi 22. Aras keyakinan yang digunakan ialah $95 \%(p<0.05)$. Bilangan replikasi yang dijalankan adalah sebanyak tiga replikasi. 


\section{HASIL DAN PERBINCANGAN}

\section{NILAI PH}

Rajah 1 menunjukkan nilai min pH ekstrak mengkudu asli (tanpa nyahasid) dengan 0,4 dan $8 \%(\mathrm{v} / \mathrm{v})$ perisa lemon dan ekstrak mengkudu ternyahasid menggunakan resin Amberlite IRA-67 dengan 0, 4 dan 8\% perisa lemon. Berdasarkan pada Rajah 1, ekstrak mengkudu asli dengan 0, 4 dan $8 \%$ penambahan perisa lemon mempunyai nilai $\mathrm{pH} 4.13 \pm 0.11,4.00 \pm 0.08$ dan $3.96 \pm 0.12$. Ketiga-tiga sampel ekstrak mengkudu asli mempunyai nilai $\mathrm{pH}$ yang bersifat asidik. Ini kerana buah mengkudu yang matang mengandungi asid organik seperti asid heksanoik, asid oktanoik dan asid dekanoik yang lebih tinggi daripada buah mengkudu yang tidak matang (Dittmar 1993). Menurut Antara et al. (2001), ujian analisis komponen asid lemak menunjukkan bahawa buah mengkudu pada tahap kematangan yang berbeza mengandungi kandungan asid lemak yang berbeza.

Manakala nilai $\mathrm{pH}$ bagi ekstrak mengkudu ternyahasid dengan 0, 4 dan 8\% penambahan perisa lemon pula lebih bersifat alkali iaitu pada lingkungan 8.7 bagi ketiga-tiga sampel. Data menunjukkan terdapat perbezaan yang signifikan $(\mathrm{p}<0.05)$ antara nilai $\mathrm{pH}$ sampel asli dengan nilai $\mathrm{pH}$ ketiga-tiga ekstrak mengkudu ternyahasid. Nilai pH meningkat dua kali ganda secara signifikan $(p<0.05)$ daripada sampel asli. Keputusan ini disokong oleh kajian yang dijalankan oleh Haslaniza et al. (2015a) dan Noor Hafiza et al. (2009) dengan penyahasidan menggunakan resin Amberlite IRA-67 mampu untuk meningkatkan nilai $\mathrm{pH}$ mengkudu dengan merendahkan keasidan jus mengkudu.

Menurut Gao et al. (2012), Amberlite IRA-67 merupakan penjerap yang baik untuk sesetengah asid organik seperti asid malik, asid sitrik, asid laktik dan asid tartarik. Haslaniza et al. (2019) melaporkan bahawa kadar penjerapan larutan asid seperti asid heksanoik dipengaruhi oleh nilai $\mathrm{pH}$. Semakin tinggi nilai $\mathrm{pH}$, semakin tinggi keupayaan penjerapan asid organik. Semasa penyahasidan, resin penukar ion menukar $\mathrm{OH}^{-}$dengan anion yang terpisah daripada asid di dalam ekstrak mengkudu lalu menyebabkan pembebasan $\mathrm{H}^{-}$di dalam jus mengkudu. Ion hidrogen $\left(\mathrm{H}^{+}\right)$akan bertindak balas dengan ion hidroksida $\left(\mathrm{OH}^{-}\right)$daripada resin untuk membentuk air. Pengurangan asid ini akan menyebabkan peningkatan nilai $\mathrm{pH}$ jus mengkudu (Calle et al. 2002). Namun begitu, penambahan bahan perisa lemon pada kepekatan yang berbeza iaitu 0, 4 dan 8\% tidak memberikan kesan yang signifikan ke atas $\mathrm{pH}$ ekstrak mengkudu asli dan ekstrak mengkudu ternyahsid.

\section{JUMLAH KANDUNGAN FENOL (TPC)}

Rajah 2 menunjukkan min jumlah kandungan fenol dalam sampel ekstrak mengkudu asli dengan 0, 4 dan 8\% perisa lemon dan sampel ekstrak mengkudu ternyahasid dengan 0, 4 dan 8\% perisa lemon. Berdasarkan data pada Rajah 2, didapati bahawa tiada perbezaan signifikan bagi kandungan fenol antara sampel asli dengan 0,4 dan $8 \%$ penambahan bahan perisa lemon. Hubungan yang sama turut kelihatan bagi sampel ekstrak mengkudu ternyahasid dengan 0, 4 dan $8 \%$ perisa lemon.

Perbezaan penambahan peratus perisa lemon tidak memberikan perubahan yang signifikan ke atas kandungan fenol di dalam buah mengkudu. Hal ini kerana, selain daripada komponen meruap yang terkandung di dalam esen lemon terdapat hanya sedikit komponen yang tidak meruap (2-15\%) di dalam minyak kulit citrus yang mempunyai ciri-ciri antioksidan seperti coumarins, psoralens dan polymethoxylated flavones (Dugo et al. 2002). Seterusnya, jumlah kandungan fenol menurun secara signifikan $(p<0.05)$ bagi ekstrak mengkudu ternyahasid dengan 0,4 dan $8 \%$ bahan perisa lemon berbanding ekstrak mengkudu asli dengan nilai bacaan masing-masing iaitu $538.02 \pm 28.74,550.28 \pm 25.38$ dan $552.77 \pm 25.67$ $\mathrm{mg} \mathrm{GAE/L}$. Data yang diperoleh ini sama seperti hasil kajian yang dilakukan oleh Noor Hafiza et al. (2009) dan Haslaniza et al. (2015a) iaitu penggunaan resin Amberlite IRA-67 telah mengurangkan jumlah kandungan fenol dalam jus mengkudu. Kajian lepas telah membuktikan bahawa kebanyakan kandungan sebatian fenol di dalam buah mengkudu adalah bersifat tidak berkutub (Zin et al. 2002). Manakala resin Amberlite IRA-67 pula mempunyai keporosan yang tinggi dan struktur matriknya yang bersifat hidrofobik yang mendorong kepada penjerapan sebatian fenol tidak berkutub melalui interaksi hidrofobik (Carmona et al. 2006) dan kuasa van der Waals (Geng et al. 2009). Justeru, terdapat kemungkinan bahawa interaksi sebatian fenol dengan resin adalah interaksi hidrofobik (Haslaniza et al. 2015a). Interaksi ini telah menyebabkan penurunan jumlah fenol di dalam jus buah mengkudu.

\section{UJIAN PENANGKAPAN RADIKAL BEBAS (DPPH)}

Aktiviti antioksidan dalam ekstrak mengkudu turut dinilai melalui ujian penangkapan radikal bebas (DPPH). Ini kerana kandungan fenol yang tinggi tidak mencukupi untuk membuktikan aktiviti antioksidan yang tinggi maka ujian DPPH juga perlu dijalankan (Chew et al. 2011). Peratusan penangkapan radikal bebas DPPH ekstrak mengkudu asli dan ekstrak mengkudu ternyahasid dengan 0, 4 dan 8\% perisa lemon boleh diperhatikan pada Rajah 3. Tiada perbezaan signifikan antara ekstrak mengkudu asli dengan penambahan 4 dan $8 \%$ bahan perisa lemon, iaitu nilai bacaan masing-masing $82.27 \pm 8.91,84.75 \pm 3.34$ dan $86.78 \pm 3.14 \%$. Situasi yang sama juga dapat diperhatikan bagi ekstrak mengkudu ternyahasid dengan 0, 4 dan 8\% bahan perisa lemon, tiada perbezaan yang ketara untuk peratusan penangkapan radikal bebas iaitu dengan nilai bacaan $62.35 \pm 3.06,64.27 \pm 2.28$ dan $65.04 \pm 2.69 \%$. 
Kapasiti antioksidan dalam ekstrak mengkudu menurun secara signifikan $(\mathrm{p}<0.05)$ selepas ternyahasid dengan resin Amberlite IRA-67. Walaupun ekstrak mengkudu segar mengandungi kandungan antioksidan yang tinggi, penyahasidan telah menyebabkan pengurangan terhadap peratusan penangkapan radikal bebas DPPH (Haslaniza et al. 2018). Nilai yang diperoleh daripada ujian DPPH ini adalah sama seperti kajian yang dilakukan oleh Fong et al. (2017). Perkara ini terjadi disebabkan oleh interaksi hidrofobik (Carmona et al. 2006) dan kuasa van der Waals (Geng et al. 2009) antara resin Amberlite IRA-67 dengan sebatian fenol yang berfungsi sebagai penangkap radikal bebas (Chan-Blanco et al. 2006; Dixon et al. 1999; Elkins 2002). Oleh itu, penurunan jumlah kandungan fenol (TPC) secara signifikan $(p<0.05)$ mungkin turut menyebabkan penurunan peratusan penangkapan radikal bebas DPPH secara signifikan $(p<0.05)$.

\section{KUASA PENURUNAN FERIK (FRAP)}

Rajah 4 menunjukkan kuasa penurunan ferik ekstrak mengkudu dengan perlakuan yang berbeza. Data yang diperoleh menunjukkan terdapat perbezaan signifikan $(p<0.05)$ antara nilai penurunan ferik ekstrak mengkudu asli dengan ekstrak mengkudu yang ternyahasid dengan semua penambahan perisa lemon. Nilai penurunan ferik ekstrak mengkudu asli iaitu $14268.82 \pm 810.24 \mu \mathrm{mol}$ $\mathrm{Fe}(\mathrm{II}) / \mathrm{mL}$ adalah lebih tinggi secara signifkan $(p<0.05)$ berbanding ekstrak mengkudu ternyahasid. Ini mungkin berpunca daripada penjerapan kumpulan polifenol di dalam jus mengkudu oleh resin penukar ion yang menyebabkan berlakunya pengurangan kapasiti antioksidan yang berupaya menurunkan Fe(III)

Nilai penurunan ferik ekstrak mengkudu ternyahasid 0,4 dan $8 \%$ perisa lemon menurun secara signifikan $(p<0.05)$ dengan nilai bacaan $5324.87 \pm 312.03 \mu \mathrm{mol}$ $\mathrm{Fe}(\mathrm{II}) / \mathrm{mL}, 5645.52 \pm 88.57 \mu \mathrm{mol} \mathrm{Fe}(\mathrm{II}) / \mathrm{mL}$ dan 5582.89 $\pm 109.23 \mu \mathrm{mol} \mathrm{Fe}(\mathrm{II}) / \mathrm{mL}$. Data ini disokong oleh kajian yang dijalankan oleh Haslaniza et al. (2015), semua jus mengkudu yang ternyahasid dengan menggunakan tiga jenis resin yang berlainan (Amberlite IRA-67 \& IRA96 dan Duolite-A7) mempunyai nilai FRAP yang lebih rendah daripada ekstrak mengkudu asli (tanpa nyahasid). Manakala penambahan perisa lemon pada kepekatan 4 dan $8 \%$ tidak memberikan perubahan yang signifikan pada ekstrak mengkudu asli dan ekstrak mengkudu ternyahasid. Ini mungkin disebabkan oleh kandungan antioksidan yang rendah pada sumber sintetik bahan perisa lemon. Menurut Jayathilakan et al. (2007), antioksidan yang diperoleh daripada sumber asli seperti bunga cengkih dan kayu manis adalah lebih tinggi berbanding antioksidan sintetik.

\section{KORELASI AKTIVITI ANTIOKSIDAN}

Jadual 1 menunjukkan korelasi antara aktiviti antioksidan berdasarkan kaedah TPC, DPPH dan FRAP. Nilai pekali korelasi, r adalah menggunakan kaedah korelasi Spearman. Korelasi positif yang tinggi dapat dilihat bagi semua kaedah iaitu kaedah TPC dengan DPPH dan FRAP dengan DPPH, masing-masing dengan nilai $r=0.943$, $\mathrm{p}<0.05$ manakala korelasi TPC dengan FRAP adalah $\mathrm{r}=0.886, \mathrm{p}<0.05$. Hal ini adalah disebabkan oleh sebatian fenol yang tinggi di dalam buah-buahan berfungsi sebagai antioksidan sekunder jenis hidrofilik (Wang \& Su 2001). Korelasi yang tinggi bagi TPC dengan FRAP juga disebabkan oleh mekanisme yang sama dengan kedua-dua kaedah melibatkan proses pengoksidaan dan pengurangan (redoks) oleh antioksidan.

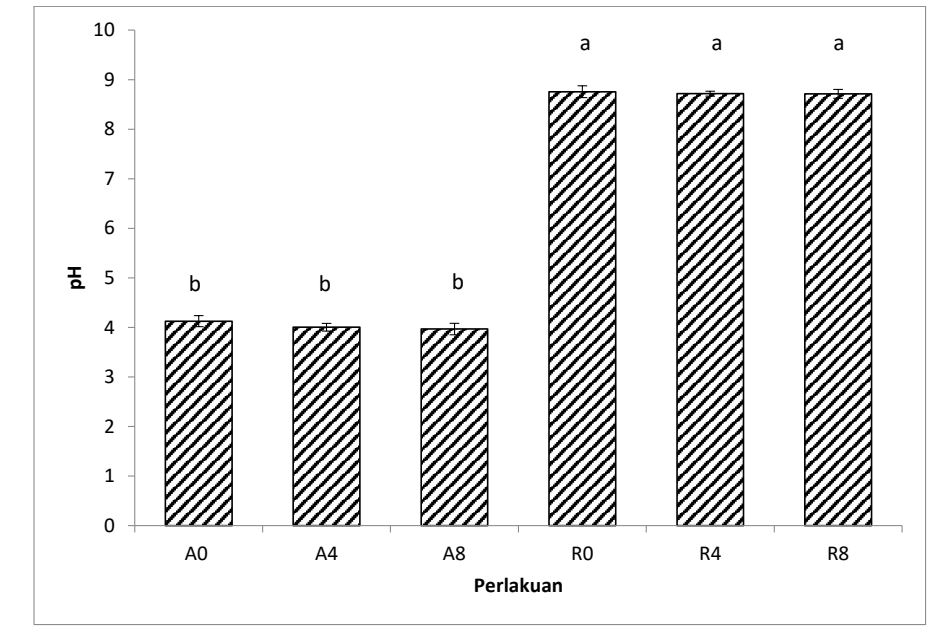

a-b Min dengan abjad yang berbeza menunjukkan perbezaan signifikan $(\mathrm{p}<0.05)$. A0 - Sampel ekstrak mengkudu asli (tanpa penyahasidan dan perisa lemon), A4 - Sampel ekstrak mengkudu asli dengan $4 \%$ perisa lemon, A8 - Sampel ekstrak mengkudu asli dengan $8 \%$ perisa lemon, R0 - Sampel ekstrak mengkudu ternyahasid dengan $0 \%$ perisa lemon, R4 - Sampel ekstrak mengkudu ternyahasid dengan $4 \%$ perisa lemon dan R8 - Sampel ekstrak mengkudu ternyahasid dengan $8 \%$ perisa lemon.

RAJAH 1. Nilai pH ekstrak mengkudu dengan perlakuan penyahasidan dan peratusan penambahan perisa lemon yang berbeza 


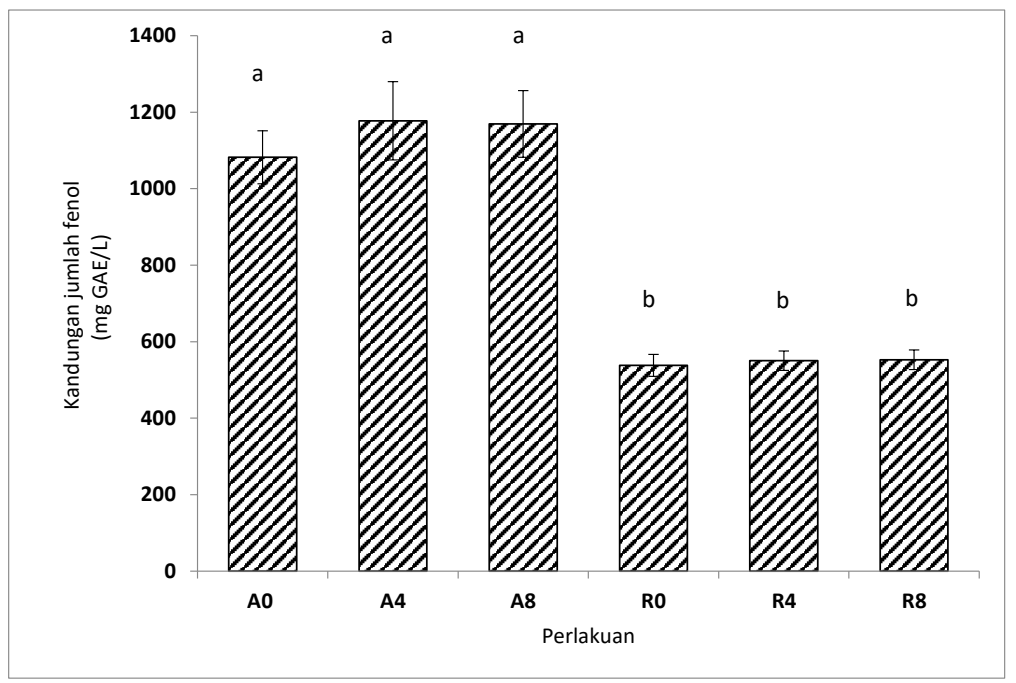

${ }^{a-b}$ Min dengan abjad yang berbeza menunjukkan perbezaan signifikan $(\mathrm{p}<0.05)$. A0 - Sampel ekstrak mengkudu asli (tanpa penyahasidan dan perisa lemon), A4 - Sampel ekstrak mengkudu asli dengan $4 \%$ perisa lemon, A8 - Sampel ekstrak mengkudu asli dengan 8\% perisa lemon, R0 - Sampel ekstrak mengkudu ternyahasid dengan $0 \%$ perisa lemon, R4 - Sampel ekstrak mengkudu ternyahasid dengan $4 \%$ perisa lemon dan R8 - Sampel ekstrak mengkudu ternyahasid dengan $8 \%$ perisa lemon.

RAJAH 2. Kandungan jumlah fenol (TPC) ekstrak mengkudu dengan perlakuan penyahasidan dan peratusan penambahan perisa lemon yang berbeza

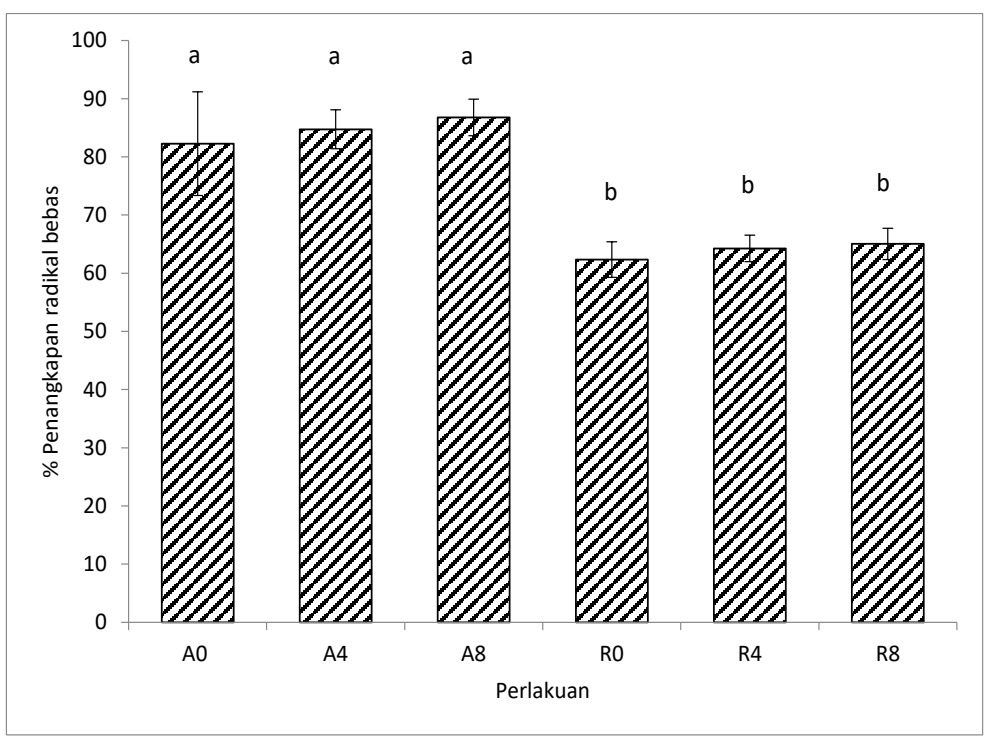

${ }^{a-b}$ Min dengan abjad yang berbeza menunjukkan perbezaan signifikan ( $\left.<<0.05\right)$. A0 - Sampel ekstrak mengkudu asli (tanpa penyahasidan dan perisa lemon), A4 - Sampel ekstrak mengkudu asli dengan $4 \%$ perisa lemon , A8 - Sampel ekstrak mengkudu asli dengan 8\% perisa lemon, R0 - Sampel ekstrak mengkudu ternyahasid dengan $0 \%$ perisa lemon, R4 - Sampel ekstrak mengkudu ternyahasid dengan $4 \%$ perisa lemon dan R8 - Sampel ekstrak mengkudu ternyahasid dengan $8 \%$ perisa lemon.

RAJAH 3. Peratusan penangkapan radikal bebas (DPPH) ekstrak mengkudu dengan perlakuan penyahasidan dan peratusan penambahan perisa lemon yang berbeza 


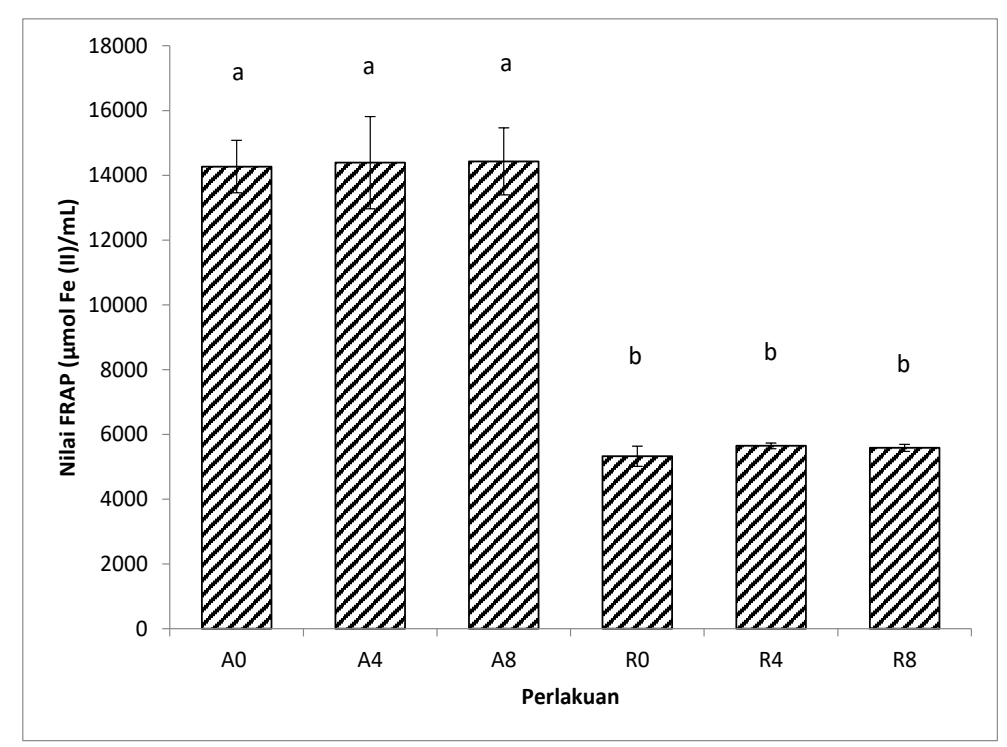

${ }^{a-b}$ Min dengan abjad yang berbeza menunjukkan perbezaan signifikan $(\mathrm{p}<0.05)$. A0 - Sampel ekstrak mengkudu asli (tanpa penyahasidan dan perisa lemon), A4 - Sampel ekstrak mengkudu asli dengan $4 \%$ perisa lemon, A8 - Sampel ekstrak mengkudu asli dengan $8 \%$ perisa lemon, R0 - Sampel ekstrak mengkudu ternyahasid dengan 0\% perisa lemon, R4 - Sampel ekstrak mengkudu ternyahasid dengan $4 \%$ perisa lemon dan R8 - Sampel ekstrak mengkudu ternyahasid dengan 8\% perisa lemon.

RAJAH 4. Nilai kuasa penurunan ferik (FRAP) ekstrak mengkudu dengan perlakuan penyahasidan dan peratusan penambahan perisa lemon yang berbeza

JADUAL 1. Pekali korelasi Spearman (r) aktiviti antioksidan bagi kaedah TPC, DPPH dan FRAP ekstrak mengkudu dengan perlakuan penyahasidan dan penambahan perisa lemon yang berbeza

\begin{tabular}{ccc}
\hline Pekali korelasi (r) & TPC & DPPH \\
TPC & & \\
DPPH & $0.943^{* *}$ & \\
FRAP & $0.886^{*}$ & $0.943^{* *}$ \\
\hline
\end{tabular}

** Korelasi signifikan pada $\mathrm{p}<0.01, *$ Korelasi signifikan pada $\mathrm{p}<0.05$.

\section{KESIMPULAN}

Nilai kandungan jumlah fenol (TPC), peratus penangkapan radikal bebas (DPPH) dan nilai kuasa penurunan ferik (FRAP) didapati menurun secara signifikan $(p<0.05)$ setelah dinyahasid menggunakan Amberlite IRA-67 berbanding dengan sampel asli (tanpa nyahasid). Nilai pH pula meningkat secara signifikan $(p<0.05)$ setelah dinyahasid. Kaedah penyahasidan berupaya untuk mengurangkan keasidan ekstrak mengkudu. Walau bagaimanapun, penambahan bahan perisa lemon ke atas eskstrak mengkudu asli dan ternyahasid tidak memberikan kesan yang signifikan ke atas ciri-ciri antioksidan. 


\section{PENGHARGAAN}

Penyelidik menyatakan penghargaan kepada Kementerian Pendidikan Malaysia atas bantuan kewangan di bawah Exploratory Research Grant Scheme melalui Geran ERGS/1/2013/STWN03/UKM/02/1

\section{RUJUKAN}

Akowuah, G.A., Ismail, Z., Norhayati, I. \& Sadikun, A. 2005. The effects of different extraction solvents of varying polarities on polyphenols of Orthosiphon stamineus and evaluation of the free radical-scavenging activity. Food Chemistry 93(2): 311-317.

Anh, K.T.B., Antony, B. \& Filomena, P. 2006. Polysaccharide composition of the fruit juice of Morinda citrifolia (Noni). Phytochemistry 67(12): 1271-1275.

Antara, N.T., Pohan, H.G. \& Subagja. 2001. Pengaruh tingkat kematangan dan proses terhadap karakteristik sari buah mengkudu. Warta IHP/J. of Agro-Based Industry 18(1-2): 25-31.

Benzie, I.F. \& Strain, J. 1996. The ferric reducing ability of plasma (FRAP) as a measure of "antioxidant power": The FRAP assay. Analytical Biochemistry 239(1): 70-76.

Calle, E.V., Ruales, J., Dornier, M., Sandeaux, J., Sandeaux, R. \& Pourcelly, G. 2002. Deacidification of the clarified passion fruit juice (P. edulis F. flavicarpa). Desalination 149(1): 357-361.

Carmona, M., Lucas, A., Valverde, J., Velasco, B. \& Rodriguez, J. 2006. Combined adsorption and ion exchange equilibrium of phenol on Amberlite IRA-420. Chemical Engineering Journal 117(2): 155-160.

Chan-Blanco, Y., Vaillant, F., Mercedes Perez, A., Reynes, M., Brillouet, J.M. \& Brat, P. 2006. The Noni fruit (Morinda citrifolia L.): A review of agricultural research, nutritional and therapeutic properties. Journal of Food Composition and Analysis 19(6-7): 645-654.

Cheah, S.L., Pung, C.L., Haslaniza, H., Sahilah, A.M. \& Maskat, M.Y. 2014. Kesan fermentasi terhadap ciri fizikokimia dan aktiviti antioksida ekstrak mengkudu (Morinda citrifolia L.). Sains Malaysiana 43(12): 1907-1913.

Chew, K.K., Khoo, M.Z., Ng, S.Y., Thoo, Y.Y., Aida, W.W. \& Ho, C.W. 2011. Effect of ethanol concentration, extraction time and extraction temperature on the recovery of phenolic compounds and antioxidant capacity of Orthosiphon stamineus extracts. International Food Research Journal 18(4): 1427-1435

Delgado-Andrade, C., Conde-Aguilera, J.A., Haro, A., Pastoriza de la Cueva, S. \& Rufián-Henares, J.Á. 2010. A combined procedure to evaluate the global antioxidant response of bread. Journal of Cereal Science 5(2): 239-246.

Dittmar, A. 1993. Morinda citrifolia L. - Use in indigenous Samoan medicine. Journal of Herbs, Spices and Medicine Plants 1(3): 77-92.

Dixon, A., McMillen, H. \& Etkin, N. 1999. Ferment this: The transformation of Noni, a traditional polynesian medicine (Morinda Citrifolia, Rubiaceae). Economic Botany 53(1): 51-68.
Dugo, G., Cotroneo, A., Verzera, A. \& Bonaccorsi, I. 2002. Composition of the Volatile Fraction of Cold-Pressed Citrus Peel Oils. London: Taylor \& Francis. pp. 1-15.

Elkins, R. 2002. The Noni Revolution: Today's Tropical Wonder that can Battle Disease, Boost Energy \& Revitalize Your Health. Utah: Woodland Publications. pp. 63-88.

Fong, E.L., Khan, M.J., Wan Aida, W.M. \& Maskat, M.Y. 2017. Effect of ion exchange resin weight and extract flow rate on the properties of starfruit (Averrhoa carambola L.) extract. International Food Research Journal 24(1): 121-125.

Gao, Q., Pan, C., Liu, F., Lu, F., Wang, D., Zhang, J. \& Zhu, Y. 2012. Adsorption characteristics of malic acid from aqueous solutions by weakly basic ion-exchange chromatography. Journal of Chromatography A 1251: 148-153.

Geng, X., Ren, P., Pi, G., Shi, R., Yuan, Z. \& Wang, C. 2009. High selective purification of flavonoids from natural plants based on polymeric adsorbent with hydrogen-bonding interaction. Journal of Chromatography A 1216(47): 8331-8338.

Haslaniza, H., Ahmad, W.Y.W., Zubairi, S.I. \& Maskat, M.Y. 2019. Effect of $\mathrm{pH}$ on adsorption of organic acids and phenolic compounds by amberlite ira 67 resin. Jurnal Teknologi 81(1): 69-81.

Haslaniza, H., Zubairi, S.I., Wan Aida, W.M. \& Maskat, M.Y. 2018. Characterizing the deacidification adsorption model of organic acids and phenolic compounds of Noni extract using weak base ion exchanger. Journal of Chemistry 2018: 1-10.

Haslaniza, H., Ahmad, W.Y.W., Hassan, O. \& Maskat, M.Y. 2015a. Interaction of antioxidants and organic acid from Noni (Morinda Citrifolia L.) juice with ion exchange resins during deodorization via deacidification. Der harma Chemica 7(9): 9-21.

Haslaniza, H., Yaacob, W.W., Zubairi, S.I. \& Maskat, M.Y. 2015b. Potential of Amberlite IRA 67 resin for deacidification of organic acids in noni juice. Der Pharma Chemica 7(12): 62-69.

Jayathilakan, K., Sharma, G.K., Radhakrishna, K. \& Bawa, A.S. 2007. Antioxidant potential of synthetic and natural antioxidants and its effect on warmed-over-flavour in different species of meat. Food Chemistry 105(3): 908-916.

Kieling, D.D. \& Prudencio, S.H. 2019. Antioxidants properties, physicochemical, and sensory quality attributes of a new soybased beverage with lemongrass and lime juice. Journal of Culinary Science and Technology 17(2): 103-117.

Khalafu, S.H.S., Wan Aida, M.W., Lim, S.J. \& Maskat, M.Y. 2017. Effects of deodorisation methods on volatile compounds, chemical properties and antioxidant activities of fucoidan isolated from brown seaweed (Sargassum sp.). Algal Research 25: 507-515.

Luckow, T., Sheehan, V., Fitzgerald, G. \& Delahunty, C. 2006. Exposure, health information and flavour-masking strategies for improving the sensory quality of probiotic juice. Appetite 47(3): 315-323.

Maskat, M.Y. \& Tan, S.M. 2011. Effect of heat treatment on the physico-chemical properties of Mengkudu (Morinda citrifolia) extract. International Food Research Journal 18(3): 966-970. 
Morton, J.F. 1992. The ocean-going Noni, or Indian mulberry (Morinda citrifolia, Rubiaceae) and some of its "colourful" relatives. Ecological Botony 46: 241-256.

Nazrul, H., Mohd Lip, Saniah, K. \& Normah, A. 2013. A new approach for reduction of chemical compounds causing undesirable odour in Morinda citrifolia fruit juice. Journal of Tropical Agriculture and Food Science 41(2): 257-264.

Noor Hafiza, Y., Maskat, M.Y., Wan Aida, W.M. \& Maaruf, A.G. 2009. Response surface optimization of deacidification process of mengkudu extract using ion-exchange resin. Prosiding Seminar Kimia Bersama UKM-ITB VIII 9-11. m.s. 444-450.

Nur Hafiza, Z., Maskat, M.Y., Wan Aida, W.M. \& Osman, H. 2010. Optimization of deacidification process for Morinda citrifolia extract using packed column of calcium carbonate. International Food Research Journal 17: 1051-1066.

Ross, I.A. 2001. Medical Plants of the World. Chemical Constituents, Traditional and Modern Medical Uses. Humana Press: New Jersey.

Singh, D.R. 2012. Morinda citrifolia L. (Noni): A review of the scientific validation for its nutritional and therapeutic properties. Journal of Diabetes and Endocrinology 3(6): $77-91$

Sin, T.C., Khalafu, S.H.S., Mustapha, W.A.W., Maskat, M.Y. \& Lim, S.J. 2018. Penyahbauan Fukoidan dan kesannya terhadap ciri fizikokimia dan aktiviti antipengoksidaan. Sains Malaysiana 47(7): 1501-1510.

Slinkard, K. \& Singleton, V.L. 1977. Total phenol analysis: Automation and comparison with manual methods. American Journal of Enology and Viticulture 28(1): 49-55.
Wang, H., Wang, C.N. \& Guo, M.R. 2019. Effects of addition of strawberry juice pre-or postfermentation on physiochemical and sensory properties of fermented goat milk. Journal of Dairy Science 102(6): 4978-4988.

Wang, M.Y. \& Su, C. 2001. Cancer preventative effect of Morinda citrifolia (Noni). Annals of the New York Academy of Sciences 952: 161-168.

Wang, M.Y., West, B., Jensen, C.J., Nowicki, D., Su, C., Palu, A.K. \& Anderson, G. 2002. Morinda citrifolia (Noni): A literature review and recent advances in Noni research. Acta Pharmacological Sinica 23(12): 1127-1141.

Yang, J., Gadi, R. \& Thomson, T. 2011. Antioxidant capacity, total phenols, and ascorbic acid content of Noni (Morinda citrifolia) fruits and leaves at various stages of maturity. Micronesica 41(2): 167-176.

Zin, Z., Abdul-Hamid, A. \& Osman, A. 2002. Antioxidative activity of extracts from Mengkudu (Morinda citrifolia L.) root, fruit and leaf. Food Chemistry 78(2): 227-231

Jabatan Sains Makanan

Fakulti Sains dan Teknologi

Universiti Kebangsaan Malaysia

43600 UKM Bangi, Selangor Darul Ehsan

Malaysia

*Pengarang untuk surat-menyurat; email: yusofm@ukm.edu.my

Diserahkan: 3 Mac 2020

Diterima: 25 September 2020 